\title{
Mathematical Modeling of Dried Green Peas: A Review
}

\author{
Ashok K. Senapati ${ }^{1}$, A.K. Varshney $^{2}$ and Vineet K. Sharma ${ }^{3}$ \\ ${ }^{1}$ Centre of Excellence on Postharvest Technology, Navsari Agricultural University, \\ Navsari- 396450 (Gujarat), India \\ ${ }^{2}$ Department of Processing and Food Engineering, College of Agricultural Engineering and \\ Technology, JAU, Junagadh-362 001(Gujarat), India \\ ${ }^{3}$ Department of Agricultural Engg., N.M. College of Agriculture, NAU, Navsari, Gujarat- \\ 396450, India \\ *Corresponding author
}

\begin{tabular}{|c|c|c|}
\hline & \multicolumn{2}{|l|}{ A B S T R A C T } \\
\hline $\begin{array}{l}\text { Ke y w or d s } \\
\text { Green peas, } \\
\text { Mathematical } \\
\text { modeling, Quality } \\
\text { characteristics }\end{array}$ & \multirow{3}{*}{\multicolumn{2}{|c|}{$\begin{array}{l}\text { Green Pea (Pisum sativum L.) is an important leguminous vegetable crop } \\
\text { grown in the world which ranks top ten among the vegetable crops. Green } \\
\text { pea has high nutritive value used in many culinary preparations and several } \\
\text { medicinal actions. Processing and preservation of green peas by } \\
\text { mathematical modeling is a major focus area and the techniques are mainly } \\
\text { used for preservation and value addition of green peas. Several researchers } \\
\text { have attempted for decades to model the drying kinetics and quality } \\
\text { parameters of green peas, which Green Peas are also compiled here briefly. }\end{array}$}} \\
\hline Article Info & & \\
\hline $\begin{array}{l}\text { Accepted: } \\
\text { 18 May } 2019 \\
\text { Available Online: } \\
\text { 10 June } 2019\end{array}$ & & \\
\hline Introduction & & \\
\hline \multicolumn{3}{|c|}{$\begin{array}{ll}\text { Pea (Pisum sativum L.) is one of the } & \text { Fabaceae family. In India, pea is grown in } \\
\text { important and popular leguminous vegetable } & \text { winter as well as summer seasons and each } \\
\text { crops grown throughout the world and is one } & \text { pea pod is having several seed of green or } \\
\text { of the most popular pulse crops of India. The } & \text { yellow colour. The fruit is a typical pod } \\
\text { major producing states are Uttar Pradesh, } & \text { containing four to nine seeds. The length of } \\
\text { Punjab, Himachal Pradesh, Orissa, Karnataka } & \text { pods is } 5 \text { to } 9 \mathrm{~cm} \text { and shape is inflated. They } \\
\text { and Haryana, etc. The area and production of } & \text { are used for the human diet for a long time } \\
\text { green peas in India is about } 5,46,000 \text { ha and } & \text { because it is an excellent source of protein, } \\
5.45 \text { million tones, respectively (NHB, 2017). } & \text { vitamins, minerals and other nutrients and low } \\
\text { The postharvest losses of green peas are about } & \text { in fat, high in fiber and contains no }\end{array}$} \\
\hline
\end{tabular}


cholesterol. Pea has high nutritive value such as carbohydrate, fiber, protein, vitamin A, vitamin $B 6$, vitamin $C$, vitamin $K$, phosphorus, magnesium, copper, iron and zinc (Nutrition, 2015). The medicinal action of green peas are antioxidant and antiinflammatory, blood sugar regulation and heart health promotion and the medicinal uses are heart disease, diabetes, stomach cancer and ulcers, etc. Due to their seasonal and perishable nature, peas must be subjected to preservation such as canning, freezing or drying in order to make them available for later consumption (Pardeshi et al., 2009; Shukla et al., 2014). Taking into consideration the seasonal availability and regional abundances along with perishability of green peas which is of vital importance in human diet, the preservation becomes an essential requirement (Lin et al., 2005). Peas are cultivated for the fresh green seeds, tender green pods, dried seeds and foliage (Duke, 1981). Green peas are eaten cooked as a vegetable and are marketed fresh, canned, or frozen while dried peas are used whole, split, or made into flour (Davies et al., 1985).

The above studies indicate the importance of some of the factor related drying of green peas in different drying condition which must be taken into consideration during the mathematical modeling. The work on the performance of drying techniques in terms drying time, moisture release pattern, depth of layer, color, outer surface condition and size of final product.

\section{Mathematical modeling of dehydrated green peas}

Mathematical modeling can play an important role in the design and control of the process parameters during fluidized bed drying. Mathematical modeling of dehydration process is an inevitable part of design, development and optimization of a dryer according to Brook and Bakker-Arkemma (1978), Bertin and Blazaquez (1986), Vagenas and Marinos-Kouris (1991). The most vital facet of food drying technique is the mathematical modeling of drying processes and apparatus (Shukla et al., 2014). The purpose of mathematical modeling is to permit designers deciding on for the most suitable operating conditions and then dimension the drying apparatus consequently to meet desired operating conditions. The theory of mathematical modeling is based on having a set of mathematical equations that can satisfactorily portray the drying system. The solution of these mathematical equations must permit forecasting of the process parameters as a function of time at any point in the drying system based only on the initial conditions (Saha et al., 2016). The best possible improvement in the quality characteristics of the product can be obtained by optimization of all the model parameters. Most of the agricultural products drying take place in falling rate drying period (Maheswari, 2015). Modeling of green peas having the tendency of high resistance for moisture diffusion can be done by simple exponential time decay model like Page, modified Page, Henderson and Pebis model, Midilli Model and Simplied Fick's diffusion equation Model, etc. (Sunil et al., 2013; Deomore and Yarasu, 2017). Empirical models help to understand the trend of experimental/process variables both dependent and independent.

Pablo Garcia Pascual et al., (2004) investigated the drying of green peas in a fluidized bed heat pump dryer under normal and atmospheric freeze drying conditions. Three types of green peas and two bed heights were used in the drying trials, operating either in isothermal conditions or on a combination of temperatures. The results show that the atmospheric freeze drying permits to obtain dried samples with high quality sensory 
properties. Drying kinetics was modelled with a diffusion model, and the effect of temperature on the effective diffusion coefficient follows the Arrhenius relationship. The activation energy values were 5046 and about $5910 \mathrm{~kJ} \mathrm{~kg}_{-}{ }^{1}$ for $8 \mathrm{~mm}$ and $10 \mathrm{~mm}$ diameter samples, respectively.

Senadeera (2005) reported the comparison effects of fixed bed and fluidized bed drying on physical property changes of spherical food materials of peas as the model material. Empirical relationships were developed for the changes in shrinkage, particle density and bulk density with moisture content for both fixed bed drying and fluidized bed drying and compared. The results revealed that physical property changes during both drying and can be modelled with respect to the moisture content. Volume shrinkage was linearly correlated and Particle densities of peas were correlated to non-linear models. In this comparison study (peas dried at $50^{\circ} \mathrm{C}$ in fixed bed and fluidized bed), lower shrinkage was experienced in fluidized bed drying compared to fixed bed drying. Low bulk density was found for the fluidized bed compared to the fixed bed. Low bulk density was also attributed to the differences in shrinkage.

Senadeera et al., (2006) investigated the changes in fluidization behavior of green peas particulates with change in moisture content during drying under a fluidized bed dryer. All drying experiments were conducted at $50 \pm$ $2^{0} \mathrm{C}$ and $13 \pm 2 \% \mathrm{RH}$ using a heat pump dehumidifier system. Fluidization experiments were undertaken for the bed heights of 100, 80, 60 and $40 \mathrm{~mm}$ at $10 \%$ moisture content levels. Fluidization behavior was best fitted to the linear model of $\operatorname{Umf}=\mathrm{A}$ $+\mathrm{B} \mathrm{e}^{-\mathrm{Cm}}$. A generalized model was also formulated using the height variation. Also generalized equation and Ergun equation was used to compare minimum fluidization velocity. With change in moisture can be predicted with an empirical model $\mathrm{U}_{\mathrm{mf}}=\mathrm{A}+$ $\mathrm{B} \mathrm{e}^{-\mathrm{Cm}}$ with a satisfactory fit $(\mathrm{L}: \mathrm{D}=1: 1)$.

According to Pardeshi et al., (2009), a thin layer drying of three varieties $(\mathrm{Pb}-87, \mathrm{~Pb}-88$ and Matar Ageta-6) of green peas was carried out in hot air drying chamber using an automatic weighing system at five temperatures (viz. 55, 60, 65, 70 and $75^{\circ} \mathrm{C}$ ) with a air velocity of $100 \mathrm{~m} / \mathrm{min}$. The green peas were blanched and sulphited (0.5\%) before drying. The result of the study revealed that the Thomson model was found to represent thin layer drying kinetics within $99.9 \%$ accuracy. The effective diffusivity was determined to be $3.95 \times 10-10$ to $6.23 \times 10$ $10 \mathrm{~m} 2 / \mathrm{s}$ in the temperature range of 55 to 75 ${ }^{\circ} \mathrm{C}$. The activation energy for diffusion was calculated to be $22.48 \mathrm{~kJ} / \mathrm{mol}$. It was found that the Thomson model could represent thin layer drying kinetics of green peas within 99.9\% accuracy.

Jadhav et al., (2010) studied a solar cabinet drying of green peas (Pisum sativum) by using response surface methodology. Thirteen experiments were conducted using a central composite design (CCD) with two variables at two levels each, viz. blanching time (1-5 min) and potassium meta bi-sulphite (KMS) concentration $(0.2-0.5 \%)$. The result of the study revealed that Page model predicted drying data was better with high $\mathrm{R}^{2}$ and low RMSE values during drying of green peas by four methods and showed the highest value of effective diffusivity.

Honarvar et al., (2011) investigated the variation of shrinkage and moisture diffusivity with temperature and moisture content for green peas under pilot scaled fluidized bed dryer (FBD) with inert particles assisted by an infra red (IR) heat source. The experimental drying curves were adjusted to the diffusion model of Fick's law for spherical particles. The result showed that, 
although the shrinkage was only a function of moisture content, the moisture diffusivity was dependent upon both temperature and moisture content. The effective diffusion coefficients were evaluated in a temperature range of $35-70^{\circ} \mathrm{C}$ and a moisture content range of $0.25-3.8 \mathrm{~kg}$ moisture $/ \mathrm{kg}$ dry solids.

Priyadarshini et al., (2013) studied two thin layer drying models; namely Page and exponential model of green peas under microwave dryer at power level of 20,40 and $60 \mathrm{~W}$. The performance of the models was evaluated by comparing the coefficient of determination $\left(\mathrm{R}^{2}\right)$ and root mean square error (RMSE). The models that best represented green pea drying were Page model.

Sunil et al., (2013) studied various mathematical modeling describing solar and sun drying of green peas. The drying data obtained from experiments were fitted to eight different mathematical models such as Newton's (Sarsavadia et al., 1999), Page (Diamante and Munro 1993), Modified page (Yaldiz et al.,2001), Henderson and Pabis (Chninman,1984), Logarithim (Yaldiz and Ertekin,2001), Wang and Singh (Wang and Singh,1978), Verma et al.,( Togrul and Pehlivan,2002) and Midilli et al.,( Midilli et al.,2002). Among the eight models, the thin layer drying model for the experimental data from bottom tray showed, the Page model was the best to describe the drying behavior of green peas with higher value of $\mathrm{R}^{2}$ and lower values of SSE, MSE and RMSE. The Midilli et al., (2002) model has shown better fit to the experimental data for top tray and open sun than other models. For the experimental data from top tray and open sun drying model showed the best fit to the drying curves with higher values of $\mathrm{R}^{2}$ and lower values of SSE, MSE and RMSE. Thus, Page model and Midilli et al., (2002) model could be used to predict the moisture ratio values and drying time of green peas.
Shukla et al., (2014) reported mathematical modeling of microwave drying of green peas. The drying characteristics of green peas were examined in a microwave dryer at power level 20,40 and $60 \mathrm{~W}$. The result of the study revealed moisture transfer from green peas was described by applying Fick's diffusion model. The drying data were fitted two thin layer drying models such as Page and exponential model. The performance of the models was evaluated by comparing the coefficient of determination $\left(\mathrm{R}^{2}\right)$, and root mean square error (RMSE). The $\mathrm{R}^{2}$ values and mean square error values shows the best fit of Page model with the experimental data for green pea.

Eshtiagh and Zare (2015) examined the drying characteristics of green peas during combined hot air infrared drying. The experiments were carried out for combination of four infrared power intensities $(0,0.2,0.4$ and $\left.0.6 \mathrm{~W} / \mathrm{cm}^{2}\right)$, three levels of drying air velocity $(0.5,1$ and $1.5 \mathrm{~m} / \mathrm{s})$, and three levels of drying air temperatures $\left(30,40\right.$ and $\left.50^{\circ} \mathrm{C}\right)$. Among several models fitted to the experimental data, The most appropriate model was the Three Term model with the values of $99.7 \%, 0.000121,0.0000$ and 0.000121 for $\mathrm{R}^{2}, \chi^{2}, \mathrm{MBE}$ and RMSE, respectively. Applying infrared power in conjunction with hot air drying led to higher drying rate in comparison with the conventional hot air drying. The effective moisture diffusivity for several drying conditions was calculated in the range from $1.39 \times 10-10$ to $5.72 \times 10-10 \mathrm{~m}^{2} / \mathrm{s}$.

\section{Quality characteristics of dried green peas}

Green Pea is nutritious vegetable with rich in crude protein, carbohydrate, vitamin $\mathrm{A}$ and $\mathrm{C}$, calcium, phosphorous, iron, zinc and dietary fibres. According to Agarwal et al., (1969) moisture content of pea lies 71.87 to $75.40 \%$ and Khurdiya et al., (1972), Kaur et al., 
(1976) and Michael Eskin (1984) also reported 76.3 to $79.2 \%$ and 75.08 to $77.48 \%$ and 71.25 to $76.01 \%$ moisture content, respectively in different varieties of peas.

Savage and Deo (1989) reported pea contains high level of protein and digestible carbohydrates and low level of fibre as well as fat. According to Renu and Bhattacharya (1989), crude protein content of peas varied from 15.0 to 29.3 per cent.

Edelenbos et al., (2001) studied chlorophyll and carotenoid pigments from six cultivars of processed green peas such as Avola, Tristar, Rampart, Turon, Bella and Greenshaft which are extracted with $100 \%$ acetone and analyzed by reversed-phase HPLC. A total of 17 pigments were identified in the pea cultivars including 8 xanthophylls. The efficiency of different extraction procedures using $100 \%$ acetone showed that initial extraction followed by three re extractions without holding time between gave a higher extraction yield than no re extraction and 30 or 60 min holding time.

According to Pardeshi et al.,(2009), a thin layer drying of three varieties $(\mathrm{Pb}-87, \mathrm{~Pb}-88$ and Matar Ageta-6) of green peas was carried out in hot air drying chamber using an automatic weighing system at five temperatures (viz. 55, 60, 65, 70 and $75^{\circ} \mathrm{C}$ ) with a air velocity of $100 \mathrm{~m} / \mathrm{min}$. The green peas were blanched and sulphited $(0.5 \%)$ before drying. The result of the study revealed that the variety $\mathrm{Pb}-87$ of green peas dried at $60^{\circ} \mathrm{C}$ was judged to be best for quality on the basis of sensory evaluation and rehydration ratio. The variation in shrinkage exhibited a linear relationship with moisture content of the product during drying. The green peas variety $\mathrm{Pb}-87$ dried at $60^{\circ} \mathrm{C}$ was found to give the best quality on the basis of sensory evaluation and rehydration ratio. The shrinkage ratio was found to be independent of drying temperature and exhibited a linear relationship with moisture content of the product during drying.

Jadhav et al., (2010) studied a solar cabinet drying of green peas (Pisum sativum) by using response surface methodology to optimize the pretreatment prior to drying. Thirteen experiments were conducted using a central composite design (CCD) with two variables at two levels each, viz. blanching time (1-5 min) and potassium meta bi-sulphite (KMS) concentration $(0.2-0.5 \%)$. They studied the, color (a value) and hardness ( $\mathrm{g}$ ) of the dehydrated green peas and found that at 4.24 min blanching time and0.49\% KMS concentration resulting into 7.86 color (a value) and $548 \mathrm{~g}$ hardness. The quality of solar cabinet dehydrated green peas was found better as compared to open sun drying as well as fluidized bed drying.

Honarvar et al., (2011) investigated the variation of shrinkage and moisture diffusivity with temperature and moisture content for green peas under pilot scaled fluidized bed dryer (FBD) with inert particles assisted by an infra red (IR) heat source. The result showed the shrinkage was only a function of moisture content.

Sunil et al., (2013) investigated the rehydration capacity of green peas in an indirect solar dryer as well as under open sun. The rehydration capacity of green peas dried in solar dryer was found higher than open sun dried peas.

Priyadarshini et al., (2013) investigated the rehydration capacities of green peas under microwave dryer at power level of 20,40 and $60 \mathrm{~W}$. The green peas were pretreated with citric acid solutions and blanched with hot water at $85^{\circ} \mathrm{C}$ before drying. The study revealed that rehydration capacities of the pretreatments were higher than control 
samples. The sensory attributes like colour, taste, texture, flavor, appearance and overall acceptability are satisfactory in hot water blanched sample dried at 40W.

Azadbakht et al., (2015) determined the effect of moisture at three levels $(47,57$, and 67 w.b. \%) on the physical properties of the Pofaki pea variety It was observed in the physical properties that moisture changes were affective at $1 \%$ in dimensions, geometric mean diameter, volume, sphericity index and the surface area. It was also observed that the moisture changes were effective at $1 \%$ on maximum deformation, rupture force, rupture energy, toughness and the power to break.

Shete et al., (2015) reported value of rehydration ratio and co-efficient of rehydration as well as dried pricked green peas samples at all drying air temperature. The sensory evaluation shows that dried pricked green peas samples were found best in colour, texture, taste, appearance and overall acceptability followed by blanched and raw dried green peas samples. The samples dried at $50^{\circ} \mathrm{C}$ earned best scores for all sensory attributes as compared to samples dried at $60^{\circ} \mathrm{C}$ and $70^{\circ} \mathrm{C}$. The value of rehydration ratio (RR) and co-efficient of rehydration (COR) were higher in case of dried pricked green peas samples at all drying air temperature. The maximum value of RR and COR were found as 1.968 and 0.617 for pricked green peas at $50^{\circ} \mathrm{C}$ drying air temperature.

In conclusion, review of different mathematical modeling of dried green peas reveals that several analytical and numerical methods are available for analyzing the drying behavior as well as quality parameters. Most of the modeling of drying kinetics has been done for hot air convective drying method. These models can be tested for other drying methods also. Moreover, there is a scope for establishing proper correlation between drying conditions and energy consumption. Further research can be done to recommend suitable method of drying and to optimize the requisite conditions for drying of green peas.

\section{References}

Agarwal, P., Rodriguez, R. and Saha, N.K. 1969. Studies on some important varieties of green peas of Northern India I. Physiochemical characteristics. Indian Food Packer. 23 (6): 12-16.

Anonymous.2017. National Horticultural Board (NHB), Gurgaon.

Azadbakht, M., Ghajarjazi, E., Aminr, E. and Abdigoal, F. (2015). Determination of some Physical amd mechanical properties of pofaki variety of pea. International Journal of Agricultural and Bio Engineering. International Scholar and Scientific Research and Innovation. Vol. 9(5): $\quad 486-493 . \quad$ Scholar.org/13076892/10001262.

Bertin, R. and Blazaquez, M. 1986. Modeling and optimization of a dryer. Drying Technol 4(1): 45-66.

Brook, R.C. and Bakker-Arkemma F.W. 1978. Dynamic programming for process optimization 1. An algorithm for design of multistage grain dryers. J Food Process Eng 2:199-211.

Chninman, M.S. (1984). Evaluation of selected mathematical models for describing thinlayer drying of inshell pecans. Transactions of the ASAE, 27, 610-615.

Davies, D.R., G.J. Berry, M.C. Heath, and T.C.K. Dawkins. 1985. Pea (Pisum sativum L.). p. 147-198. In: R.J. Summerfield and EH Roberts, (eds.), Williams Collins Sons and Co. Ltd, London, UK.

Deomore, D. N. and Yarasu, R. B. 2017. Mathematical modeling and Simulation of fluidized bed drying System. International Journal of Application or Innovation in Engineering \& Management, 6(1): 52-60. 
Diamante, L.M. and Munro, P.A. 1993. Mathematical modeling of thin layer solar drying of sweet potato slices. Solar Energy, 51(4), 271-276.

Duke, J.A. 1981. Hand book of legumes of world economic importance. Plenum Press, New York. p. 199-265.

Edelenbos, M., Christensen, L.P. and Grevsen, K. 2001. HPLC determination of chlorophyll and carotenoid pigments in processed green pea (Pisum sativum L.) cultivars. J. Agric. Food Chem. Oct, 49(10):4768-74.

Eshtiagh, A. and Zare, D. 2015. Modeling of thin layer hot air-infrared drying of green peas. Agricultural Engineering International: The CIGR e-Journal 2015: 246-258.

Gekas, V. and Lamberg I. 1991. Determination of diffusion coefficients in volume changing systems- application in the case of potato drying. J Food Eng 13: 317-326.

Honarvar, B., Safekordi, M. D. and Ali, A.S. 2011. Physical properties of green peas in an inert medium Fluidized Bed Dryer Assisted by Infrared red heating. Iran. J. Chem. Chem. Eng. Vol. 32, No. 1:107118.

Jadhav, D. B., Visavale, G. L., Sutar, N., Annapure, U. S. and Thorat, B. N. 2010. Studies on Solar Cabinet Drying of Green Peas (Pisum sativum). Drying Technology, 28:

DOI:

10.1080/07373931003788064:600-607.

Kaur, G., Shukla, F.C. and Singh, D. 1976. Studies on varietal differences in physiochemical characteristics of some varieties of peas.Indian Food Packer. 30 (4): 5-9.

Khurdiya, D.S., Ambadan, Muralikrishna, M., Phal, R. and Chaudhoury, B. 1972. Varietal trial on dehydration of peas. Indian Food Packer. 26 (4): 5-7.

Lin, D.L. and Lee, Y.C. 2005.The development of vacuum cooling technology in Taiwan. Proceedings of a symposium on research and application of postharvest technology of horticultural crops. Agricultural
Research Institute, COA. Taichung, Taiwan.

Maheswari, S. U. 2015. Drying of Pearl Millet Using Fluidized Bed Dryer: Experiments and Modeling. International Journal of Chem Tech Research, 8(1): 377-387.

Michael and Eskin, N.A. 1984. Quality and preservation of vegetables. CRC Press Inc., Boca Raton, Florida.

Midilli, A., Kucuk, H. and Yapar, Z. 2002.A new model for single layer drying. Drying Technology, 20(7), 1503-1513.

Mulet, A., Berna, A. and Rossello, C. 1989. Drying of carrots. I. Drying models. Drying Technol 7(3): 537-557.

Nanda, S.K., Vishwakarma, R.K., Bathla, H.V.L., Rai, A. and Chandra, P. 2012. Harvest and Post harvest losses of major crops and livestock produce in India. All India Coordinated Research Project on Post Harvest Technology, (ICAR), Ludhiana pp: 15-16.

Nutrition Facts.2015. Peas". Nutrition. Vegonline.org. Retrieved February 28.

Pablo García-Pascual1, Odilio Alves-Filho, Ingvald Strømmen and Trygve, M. E. 2004. Heat Pump atmospheric freeze drying of green peas. Drying 2004 Proceedings of the 14th International Drying Symposium (IDS 2004) São Paulo, Brazil, 22-25 August, Vol. C, pp. 15211528.

Pardeshi, I.L., Arora, S. and Boker, P.A. 2009. Thin layer drying of green peas and selection of a suitable thin layer drying model. Drying Technology, Vol.27:288295.

Perry, J.L. 1985. Mathematical modeling and computer simulation of heat and mass transfer in agricultural grain drying: a review. J Agric Eng Res 32:1-29.

Priyadarshini, Shukla, R.N. and Mishra, A. A. 2013. Microwave drying characteristics of green peas and its quality evaluation. International Journal of Agriculture and Food Science Technology. Volume 4, Number 5 pp. 445-452.

Renu and Bhattacharya, L. 1989. Proximate composition of improved genotype of peas 
(Pisum sativum). Bull. Grain Technol. 27: 118-123.

Saha, S.N., Dewangan, G.P. and Thakur, R.S. 2016. Modeling and Simulation of Fluidized Bed Drying of Chickpea. International Advanced Research Journal in Science, Engineering and Technology, 3(3):99-106.

Sarsavadia, P.N., Sawhney R.L., Pangavhane D.R. and Singh S.P. Drying behaviour of brined onion slices. J. of Food Engineering 1999, 40, 219-226.

Savage, G.P. and Deo, S. 1989. The nutritional value of peas (Pisum sativum): A literature review. Nutrition Abstracts and Reviews(series A). 59: 66-83.

Senadeera, W. 2005. Comparison of the effects of fixed bed and Fluidized bed drying on physical property changes of spherical food Materials using peas as the model material. Proceedings 2nd International Conference on Innovations in Food Processing Technology and Engineering, Asian Institute of Technology, Bangkok, pp: 288-296.

Senadeera, W., Wijesinghe, B., Young, G. and Bhandari, B. 2006.Fluidization Characteristics of Moist Food Particles. International Journal of Food Engineering, 2(1):1047.

Sereno, A.M. and Medeiros, G.L. 1990. A simplified model for the prediction of drying rates for foods. J Food Eng 12:111.

Shete, Y.V., More, M.M., Deshmukh, S.S. and Karne, S.C.2015. Effects of pre treatments and drying temperatures on the quality of dried green peas. International Journal of Agricultural Engineering, VOL.8 (2) DOI:10.15740/HAS/IJAE/8.2/220-226..e 8.

Shukla, R.N., Priyadarshini and Mishra, A.A. 2014.An Experimental Study and Mathematical Modeling of Microwave Drying of Green Peas. International Journal of Advances in Engineering \& Technology, 6(6): 2618-2624.

Sunil, Varun and Sharma, N. 2013. Modeling the drying kinetics of green peas in a solar dryer and under open sun. International Journal of Energy and Environment, 4(4):663-676.

Togrul, I.T. and Pehlivan, D. 2002.Mathematical modeling of solar drying of apricots in thin layers. J. of Food Engineering, 55, 209-216.

Tong, C.H. and Lund, D.B. 1990. Effective moisture diffusivity in porous materials as a function of temperature and moisture content. Biotechnol. Prog 6:67-75.

Vagenas, G.K. and Marinos-kouris, D. 1991.The design and optimization of an industrial dryer for sultana raisins. Drying Technol. 9 (2):439-461.

Wang, C.Y. and Singh, R.P. 1978.A single layer drying equation for rough rice. ASAE Paper No: 78-3001, ASAE, St. Joseph, MI.

Yaldiz, O., Ertekin, C. and Uzun, H.I. 2001. Mathematical modeling of thin layer solar drying of Sultana grapes. Energy, 26, 457465.

\section{How to cite this article:}

Ashok K. Senapati, A.K. Varshney and Vineet K. Sharma. 2019. Mathematical Modeling of Dried Green Peas: A Review. Int.J.Curr.Microbiol.App.Sci. 8(06): 3232-3239.

doi: https://doi.org/10.20546/ijcmas.2019.806.385 